2017

\title{
A review of the occurrence of pharmaceuticals and personal care products in Indian water bodies
}

Keshava Balakrishna

MANIPAL INSTITUTE OF TECHNOLOGY

Amlan Rath

The Ohio State University

Yerabham Praveenkumarreddy

MANIPAL INSTITUTE OF TECHNOLOGY

Keerthi Siri Guruge

National Institute of Animal Health, National Agriculture and Food Research Organization, Tsukuba, Ibaraki, Japan

Bikram Subedi

Murray State University, bsubedi@murraystate.edu

Follow this and additional works at: https://digitalcommons.murraystate.edu/faculty

Part of the Environmental Chemistry Commons, Environmental Health and Protection Commons, Environmental Monitoring Commons, and the Natural Resources and Conservation Commons

\section{Recommended Citation}

Balakrishna, Keshava; Rath, Amlan; Praveenkumarreddy, Yerabham; Guruge, Keerthi Siri; and Subedi, Bikram, "A review of the occurrence of pharmaceuticals and personal care products in Indian water bodies" (2017). Faculty \& Staff Research and Creative Activity. 15.

https://digitalcommons.murraystate.edu/faculty/15

This Journal Article is brought to you for free and open access by Murray State's Digital Commons. It has been accepted for inclusion in Faculty \& Staff Research and Creative Activity by an authorized administrator of Murray State's Digital Commons. For more information, please contact msu.digitalcommons@murraystate.edu. 


\section{A review of the occurrence of pharmaceuticals and personal care products in Indian water bodies}

Article in Ecotoxicology and Environmental Safety · December 2016

DOI: 10.1016/j.ecoenv.2016.11.014

CITATIONS

3

5 authors, including:

\section{Keshava Balakrishna}

Manipal University

46 PUBLICATIONS 353 CITATIONS

SEE PROFILE

\section{Keerthi S. Guruge}

National Agriculture and Food Research Orga... 69 PUBLICATIONS 1,715 CITATIONS

SEE PROFILE
Yerabham Praveenkumarreddy

Manipal University

8 PUBLICATIONS 13 CITATIONS

SEE PROFILE

Bikram Subedi

Murray State University

26 PUBLICATIONS 368 CITATIONS

SEE PROFILE 


\title{
A review of the occurrence of pharmaceuticals and personal care products in Indian water bodies
}

\author{
Keshava Balakrishna ${ }^{\mathrm{a}}$, Amlan Rath ${ }^{\mathrm{a}, \mathrm{b}}$, Yerabham Praveenkumarreddy ${ }^{\mathrm{a}}$, Keerthi Siri Guruge ${ }^{\mathrm{c}}$, \\ Bikram Subedi ${ }^{\mathrm{d}, *}$ \\ ${ }^{a}$ Department of Civil Engineering, Manipal Institute of Technology, Manipal University, Manipal 576 104, India \\ b Department of Civil, Environmental and Geodetic Engineering, The Ohio State University, Columbus, OH 43210, USA \\ c Pathology and Pathophysiology Research Division, National Institute of Animal Health, National Agriculture and Food Research Organization, Tsukuba, Ibaraki 305 859, \\ Japan \\ d Department of Chemistry, Murray State University, 1201 Jesse D Jones Hall, Murray, KY 42071, USA
}

A R T I C L E I N F O

\section{Keywords:}

Pharmaceuticals

Wastewater

Wastewater treatment plant

River

Groundwater

India

\begin{abstract}
A B S T R A C T
Little information exists on the occurrence and the ultimate fate of pharmaceuticals in the water bodies in India despite being one of the world leaders in pharmaceutical production and consumption. This paper has reviewed 19 published reports of pharmaceutical occurrence in the aquatic environment in India [conventional activated sludge wastewater treatment plants (WTPs), hospital WTPs, rivers, and groundwater]. Carbamazepine (antipsychoactive), atenolol (antihypertensive), triclocarban and triclosan (antimicrobials), trimethoprim and sulfamethoxazole (antibacterials), ibuprofen and acetaminophen (analgesics), and caffeine (stimulant) are the most commonly detected at higher concentrations in Indian WTPs that treat predominantly the domestic sewage. The concentration of ciprofloxacin, sulfamethoxazole, amoxicillin, norfloxacin, and ofloxacin in Indian WTPs were up to 40 times higher than that in other countries in Europe, Australia, Asia, and North America. A very few studies in Indian rivers reported the presence of ciprofloxacin, enoxacin, ketoprofen, erythromycin, naproxen, ibuprofen, diclofenac and enrofloxacin. Similar compounds were reported in rivers in China, indicating a similar usage pattern in both of these developing countries. In a study reported from an open well in southern India, the groundwater showed the presence of cetirizine, ciprofloxacin, enoxacin, citalopram and terbinafine, which was close to a WTP receiving effluents from pharmaceutical production.
\end{abstract}

\section{Introduction}

Pharmaceuticals and personal care products (PPCPs) include active ingredients of prescription and non-prescription drugs for human and veterinary use, disinfectants, illicit drugs, body lotions, etc. (Kaplan, 2013; Bu et al., 2013). The PPCPs thus consumed evoke a specific biological response from the host, after which are ultimately discharged into the environment. Hirsch et al. (1999) and Kummerer (2009) have reported that $\sim 10-90 \%$ of the administered dose of PPCPs are excreted from the human body in their parent form, while the rest are excreted as metabolites and/or conjugated forms. The excreted PPCPs reach the wastewater treatment plants (WTPs) and finally discharge raw or treated effluent into the groundwater, rivers, lakes, oceans, and soil (Fig. 1). They have been detected in the aquatic environment since the 1970s (Veach and Bernot. 2011 and references therein), and in the last twenty years, in all types of surface water, groundwater and the oceanic environment (WHO, 2011; Klosterhaus et al., 2013; Luo et al., 2014). In the aquatic environment, PPCPs can be toxic to certain aquatic organisms and trigger antibiotic resistance amongst pathogens (Behera et al., 2011; Kidd et al., 2007; Xiao et al., 2001; Kolpin et al., 2002; Kristiansson et al., 2011). Nevertheless, limited literature exists for establishing the effects of a cocktail of PPCP mixture in the environment, on the aquatic biota and the humans (Tixier et al., 2003; Daughton and Ternes, 1999).

India is among the top five producers of pharmaceutical chemicals, with an expected turnover of USD 45 billion per year by 2020 (KPMG International, 2006). The organized sector of Indian pharmaceuticals consists of around 250-300 companies, with its drug exports growing $30 \%$ annually (KPMG International, 2006). In other words, every third pill taken in the world is manufactured in India. Among the bulk formulations, around $80 \%$ have been reported to be consumed indigenously (Kallummal and Bugalya, 2012). On the other hand, treatment capacity of domestic sewage in India is far below the quantity of sewage generated from 1.3 billion people; only $31 \%$ of the total sewage

\footnotetext{
* Corresponding author.

E-mail address: bsubedi@murraystate.edu (B. Subedi).
} 


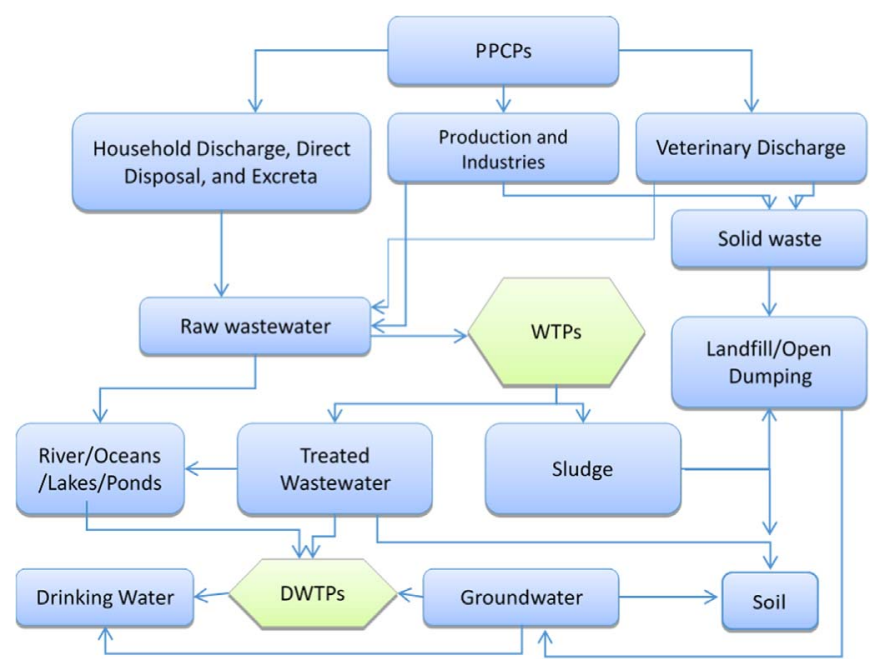

Fig. 1. Flow diagram of the PPCP pathways in the environment. WTPs: Wastewater treatment plants, DWTPs: Drinking water treatment plants.

produced ( $\sim 38,254$ million liters per day) in 908 cities were treated in 2008 (Subedi et al., 2015a).

Despite high rates of production and consumption of PPCPs across the country and shortage in demand and supply for the sewage treatment, limited literature is available to account for their occurrence, transport, and fate in the aquatic environment (Subedi et al., 2015a; Subedi et al., 2015b; Rehman et al., 2013; Mutiyar and Mittal, 2014). This review provides an overview of levels of PPCP contamination in Indian water bodies, which can potentially trigger more large-scale nationwide studies on the occurrence of PPCPs and their ecological impacts. The pharmaceutical residue levels in domestic wastewater, hospital effluent, river water, and groundwater in India are compared with that reported elsewhere. Finally, recommendations for an efficient management of PPCP contamination in the aquatic environment, that are important for the sustainable solution, are provided.

\section{Pharmaceutical contaminants in India}

\subsection{Wastewater treatment plants}

Twelve studies have reported the pharmaceuticals in wastewater from conventional activated sludge treatment based WTPs in India (Larsson et al., 2007; Fick et al., 2009; Mutiyar and Mittal, 2013a, 2014; Singh et al., 2014; Akiba et al., 2015; Subedi et al., 2015a; Prabhasankar et al., 2016; Archana et al., 2016; Mohapatra et al., 2016; Anumol et al., 2016; Subedi et al., 2017) (Table 1).

WTP outlets are the primary point sources of pharmaceutical contamination in the rivers and oceans (Daughton and Ternes, 1999). The existing wastewater treatment processes are incapable of removing most of the pharmaceutical contaminants; removal efficiencies typically ranged from $12.5 \%$ to $100 \%$ (Santos et al., 2007; Luo et al., 2014). The microbial transformation and/or deconjugation of glucuronides of the select pharmaceuticals and their active metabolites can have negative removal efficiency (Subedi et al., 2015a). Removal efficiency depends on the treatment process, sludge age, the geography of the area, and the rainfall rate (Chen et al., 2012). The overall pharmaceutical contamination profile is also dependent on the pharmaceutical production and usage pattern (Behera et al., 2011).

\subsubsection{WTP receiving effluents from pharmaceutical industries}

Despite of relatively lower levels (ng/L to $\mu \mathrm{g} / \mathrm{L}$ ) of pharmaceuticals in wastewater from WTPs that process predominantly domestic sewage, much higher concentrations (mg/L) of pharmaceutical contaminants were reported from the WTPs that process wastewater from the

Table 1

Mean reported concentrations of pharmaceuticals and their metabolites in wastewater (ng/L) from wastewater treatment plants (WTPs) in India.

\begin{tabular}{lll}
\hline Contaminants & Influent & Effluent \\
\hline Antischizophrenics & & \\
Quetiapine & $38^{\mathrm{a}}, 15^{\mathrm{b}}, 36.8^{\mathrm{k}}, 20.8^{1}$, & $20^{\mathrm{a}}, 5.2^{\mathrm{b}}, 6.32^{1}$, \\
& $24.8^{\mathrm{m}}, 13.8^{\mathrm{n}}, 71.2^{\circ}$ & $16.6^{\mathrm{m}}, 22.4^{\circ}$ \\
Noquetiapine & $1.87^{\mathrm{k}}, 6.78^{\mathrm{l}}, 4.70^{\mathrm{m}}, 10.7^{\mathrm{n}}$, & $4.04^{\mathrm{k}}, 10.1^{\mathrm{m}}, 1.92^{\mathrm{n}}$, \\
& $16.4^{\mathrm{o}}$ & $6.50^{\circ}$ \\
Aripiprazole & $44^{\mathrm{a}}, 29^{\mathrm{b}}, 4.20^{\mathrm{l}}, 14^{\mathrm{m}}$, & $71^{\mathrm{a}}, 0.4^{\mathrm{b}}$ \\
Dehydroaripiprazole & $3.80^{\mathrm{k}}, 0.90^{\mathrm{l}}$ & $2.20^{\mathrm{k}}$ \\
& & \\
Sedatives-hypnotics-anxiolytics & \\
Lorazepam & $46^{\mathrm{a}}, 26^{\mathrm{b}}, 23.6^{\mathrm{n}}, 19.8^{\circ}$ & $23^{\mathrm{a}}, 12^{\mathrm{b}}, 19.1^{\mathrm{k}}, 27.4^{1}$, \\
& & $24.4^{\mathrm{m}}, 8.26^{\mathrm{n}}, 41.8^{\circ}$ \\
Alprazolam & $41^{\mathrm{a}}, 10.1^{\mathrm{k}}, 4.20^{1}, 6.98^{\circ}$ & $33^{\mathrm{a}}, 25^{\mathrm{b}}, 6.94^{\mathrm{k}}, 5.72^{1}$, \\
& & $2.52^{\circ}$ \\
a-hydroxyalprazolam & & $8.48^{\mathrm{k}}$ \\
Diazepam & $23^{\mathrm{a}}, 25^{\mathrm{b}}, 6.80^{\mathrm{k}}, 4.46^{1}$, & $36^{\mathrm{a}}, 9.5^{\mathrm{b}}, 8.20^{\mathrm{k}}, 47.0^{1}$, \\
& $6.66^{\mathrm{n}}, 196^{\circ}$ & $24.6^{\mathrm{n}}, 238^{\circ}$ \\
Oxazepam & $140^{\mathrm{a}}, 50^{\mathrm{b}}, 25.0^{\mathrm{m}}, 13.7^{\circ}$ & $85^{\mathrm{a}}, 50^{\mathrm{b}}, 38.2^{\mathrm{m}}$, \\
& & $17.0^{\mathrm{n}}, 17.0^{\circ}$ \\
Nordiazepam & $12^{\mathrm{a}}, 5.9^{\mathrm{b}}, 11.4^{\mathrm{k}}, 5.40^{1}$, & $85^{\mathrm{a}}, 50^{\mathrm{b}}, 10.5^{\mathrm{k}}, 6.70^{1}$, \\
Carbamazepine & $14.5^{\mathrm{m}}, 3.26^{\mathrm{n}}, 12.4^{\circ}$ & $8.56^{\mathrm{m}}, 3.08^{\mathrm{n}}, 5.96^{\circ}$ \\
& $450^{\mathrm{a}}, 550^{\mathrm{b}}, 470^{\mathrm{d}}, 650^{\mathrm{e}}$, & $580^{\mathrm{a}}, 480^{\mathrm{b}}, 88^{\mathrm{k}}, 236^{1}$, \\
& $5800^{\mathrm{i}}, 8200^{\mathrm{j}}, 82.2^{\mathrm{k}}, 270^{1}$, & $900^{\mathrm{m}}, 147^{\mathrm{n}}, 318^{\circ}$ \\
& $840^{\mathrm{m}}, 22.0^{\mathrm{n}}, 726^{\circ}$ & \\
& & \\
& & \\
& & \\
& &
\end{tabular}

Antidepressants

Venlafaxine

Bupropion

Sertraline

Nosertraline

Citalopram

Antihypertensives

Propranolol

Atenolol

Metoprolol

Diltiazem

Desacetyl diltiazem

Verapamil

Norverapamil

Antimicrobial

Triclocarban

Triclosan

Antibiotics/fungicides

Trimethoprim

Sulfamethoxazole

Ampicilin

Ciprofloxacin

Erythromycin

Gatifloxacin

Levofloxacin

Nofluoxacin

Azithromycin

Sparfloxacin

Cefuroxime

Ofloxacin

Clindamycin $38^{\mathrm{a}}, 5^{\mathrm{b}}, 30.6^{\mathrm{k}}, 10.3^{\mathrm{l}}, 138^{\mathrm{m}}$, $9.30^{\mathrm{n}}, 46.2^{\circ}$

$19^{\mathrm{a}}, 23^{\mathrm{b}}$

$23^{\mathrm{a}}, 40^{\mathrm{b}}, 5.33^{\mathrm{k}}, 2.53^{\mathrm{l}}$,

$87.0^{\mathrm{m}}, 10.6^{\mathrm{n}}, 21.8^{\circ}$

$116^{\mathrm{k}}, 144^{1}, 386^{\mathrm{m}}$

$7.16^{1}, 16.4^{\mathrm{n}}, 31.8^{\mathrm{o}}$

$51^{\mathrm{a}}, 43^{\mathrm{b}}, 17.0^{\mathrm{k}}, 18.5^{\mathrm{l}}$,

$34.2^{\mathrm{m}}, 14.5^{\mathrm{n}}, 123^{\circ}$

$2900^{\mathrm{a}}, 1400^{\mathrm{b}}, 41400^{\mathrm{i}}$,

$13800^{\mathrm{j}}, 1010^{\mathrm{k}}, 374^{1}$,

$2440^{\mathrm{m}}, 192^{\mathrm{n}}, 1910^{\circ}$

$35500^{\mathrm{i}}, 11800^{\mathrm{j}}$

$55^{\mathrm{a}}, 16^{\mathrm{b}}, 5.64^{\mathrm{n}}, 1.39^{\circ}$

$32^{\mathrm{a}}, 6.40^{\mathrm{k}}, 1.04^{1}, 7.62^{\mathrm{m}}$,

$1.55^{\mathrm{n}}, 44.4^{\mathrm{o}}$

$36^{\mathrm{a}}, 25^{\mathrm{b}}, 1.74^{\mathrm{k}}, 0.74^{\mathrm{l}}$

$0.61^{\circ}$

$260^{\mathrm{a}}, 47^{\mathrm{b}}, 0.88^{\mathrm{k}}, 4.04^{\mathrm{m}}$,

$2400^{\mathrm{a}}, 4000^{\mathrm{b}}, 515^{\mathrm{k}}, 933^{1}$, $8880^{\mathrm{m}}, 1150^{\mathrm{n}}, 2100^{\circ}$

$4890^{\mathrm{f}}, 450^{\mathrm{k}}, 145^{\mathrm{l}}, 2500^{\mathrm{m}}$, $892^{\mathrm{n}}, 2440^{\circ}$

$180^{\mathrm{a}}, 29^{\mathrm{b}}, 4010^{\mathrm{d}}, 210^{\mathrm{e}}, 3^{\mathrm{h}}$, $4^{\mathrm{h}}, 23^{\mathrm{h}}, 33.0^{\mathrm{k}}, 90.8^{\mathrm{l}}, 156^{\mathrm{m}}$, $160^{\mathrm{n}}, 35.6^{\circ}$

$220^{\mathrm{a}}, 100^{\mathrm{b}}, 3^{\mathrm{h}}, 66^{\mathrm{h}}, 195^{\mathrm{k}}$,

$288^{1}, 552^{\mathrm{m}}, 414^{\mathrm{n}}, 2260^{\circ}$

$104.2^{\mathrm{c}}$

$20.06^{\mathrm{c}}, 12900^{\mathrm{f}}$

$12^{\mathrm{h}}$

$2.74^{c}$

$86700^{\mathrm{i}}, 107900$

$18200^{\mathrm{i}}$

$176900^{\mathrm{i}}, 29300^{\mathrm{i}}$

$22.49^{\mathrm{c}}$

$3.42^{\mathrm{C}}$

$210^{\mathrm{a}}, 31^{\mathrm{b}}, 5.16^{\mathrm{k}}, 18.3^{1}$, $27.2^{\mathrm{m}}, 49.6^{\mathrm{n}}, 1870^{\circ}$ $15^{\mathrm{a}}, 5^{\mathrm{b}}, 6.70^{\mathrm{k}}, 7.96^{\mathrm{l}}$, $105^{\mathrm{m}}, 7.26^{\mathrm{n}}, 29.4^{\mathrm{o}}$ $14^{\mathrm{a}}, 5^{\mathrm{b}}, 3.80^{\mathrm{k}}, 3.42^{\mathrm{o}}$ $18^{\mathrm{a}}, 1.7^{\mathrm{b}}, 59.8^{\mathrm{m}}$, $10.8^{\circ}$

$55.6^{\mathrm{k}}, 57.6^{\mathrm{l}}, 50.0^{\mathrm{m}}$

$9.46^{\mathrm{m}}, 14.7^{\mathrm{n}}, 29.8^{\circ}$

$43^{\mathrm{a}}, 28^{\mathrm{b}}, 7.98^{\mathrm{k}}, 11.8^{\mathrm{l}}$ $37.6^{\mathrm{m}}, 11.4^{\mathrm{n}}, 12.3^{\circ}$ $1500^{\mathrm{a}}, 590^{\mathrm{b}}, 197^{\mathrm{k}}$, $244^{1}, 2500^{\mathrm{m}}, 16.3^{\mathrm{n}}$, $772^{\circ}$

$5^{\mathrm{a}}, 1.8^{\mathrm{b}}, 1.52^{\mathrm{m}}, 1.53^{\mathrm{o}}$ $44^{\mathrm{a}}, 10^{\mathrm{b}}, 3.02^{\mathrm{k}}, 1.82^{\mathrm{l}}$, $8.96^{\mathrm{m}}, 1.51^{\mathrm{n}}, 20.0^{\circ}$

$2^{\mathrm{a}}, 0.88^{1}, 1.08^{\mathrm{m}}, 2.64^{\circ}$

$4^{\mathrm{a}}, 1.46^{\mathrm{m}}$,

$540^{\mathrm{a}}, 260^{\mathrm{b}}, 22.4^{\mathrm{k}}$ $457^{1}, 5860^{\mathrm{m}}, 48.4^{\mathrm{n}}$, $375^{\circ}$ $3500^{\mathrm{f}}, 2500^{\mathrm{m}}, 202^{\mathrm{n}}$

$25^{\mathrm{b}}, 8^{\mathrm{h}}, 1^{\mathrm{h}}, 3^{\mathrm{h}}, 34.8^{\mathrm{k}}$, $38.0^{\mathrm{l}}, 103^{\mathrm{m}}, 2080^{\circ}$

$260^{\mathrm{a}}, 25^{\mathrm{b}}, 13^{\mathrm{h}}, 27^{\mathrm{h}}$, $9^{\mathrm{h}}, 70.2^{1}, 318^{\mathrm{m}}, 228^{\mathrm{n}}$, $296^{\circ}$

$12.68^{\mathrm{C}}$ $8^{\mathrm{c}}, 11670^{\mathrm{f}}$ $2^{\mathrm{h}}, 1^{\mathrm{h}}, 9^{\mathrm{h}}$ 1.22

$0.14^{c}$

$0.22^{\mathrm{c}}$

$0-212^{\mathrm{g}}$

$25^{\mathrm{b}}, 48.0^{\mathrm{k}}, 6.96^{\mathrm{l}}$,

$17.5^{\mathrm{m}}, 63.8^{\mathrm{n}}, 952^{\circ}$

(continued on next page) 
Table 1 (continued)

\begin{tabular}{|c|c|c|}
\hline Contaminants & Influent & Effluent \\
\hline Lincomycin & $\begin{array}{l}730^{\mathrm{a}}, 230^{\mathrm{b}}, 15.2^{\mathrm{k}}, 20.8^{\mathrm{l}}, \\
226^{\mathrm{n}}, 148^{\mathrm{o}}\end{array}$ & $\begin{array}{l}430^{\mathrm{a}}, 130^{\mathrm{b}}, 53.0^{\mathrm{k}}, \\
17.5^{\mathrm{l}}, 3.92^{\mathrm{m}}, 187^{\mathrm{n}} \\
43.0^{\circ}\end{array}$ \\
\hline Miconazole & $\begin{array}{l}67^{\mathrm{a}}, 42^{\mathrm{b}}, 23.4^{\mathrm{k}}, 65.6^{1}, \\
1410^{\mathrm{m}}, 46^{\mathrm{n}}, 894^{\circ}\end{array}$ & $\begin{array}{l}8.0^{\mathrm{a}}, 25^{\mathrm{b}}, 17.8^{\mathrm{k}}, 8.92^{1}, \\
1020^{\mathrm{m}}, 17.0^{\circ}\end{array}$ \\
\hline Tiabendazole & $64^{\mathrm{a}}, 123^{\mathrm{b}}$ & $79^{\mathrm{a}}, 25^{\mathrm{b}}$ \\
\hline \multicolumn{3}{|l|}{ Analgesics } \\
\hline Ibuprofen & $\begin{array}{l}1200^{\mathrm{a}}, 1400^{\mathrm{b}}, 2380^{\mathrm{d}}, \\
1430^{\mathrm{e}}, 1130^{\mathrm{k}}, 686^{\mathrm{l}}, \\
2140^{\mathrm{m}}, 834^{\mathrm{n}}, 4460^{\circ}\end{array}$ & $\begin{array}{l}980^{\mathrm{a}}, 630^{\mathrm{b}}, 204^{\mathrm{l}}, \\
1890^{\mathrm{m}}, 145^{\mathrm{n}}\end{array}$ \\
\hline Acetaminophen & $\begin{array}{l}9000^{\mathrm{a}}, 4500^{\mathrm{b}}, 11500^{\mathrm{f}}, \\
86800^{\mathrm{i}}, 7100^{\mathrm{j}}\end{array}$ & $690^{\mathrm{a}}, 340^{\mathrm{b}}$ \\
\hline Ketoprofen & $\begin{array}{l}1080^{\mathrm{d}}, 200^{\mathrm{e}}, 39.6^{\mathrm{k}}, 52.2^{1}, \\
9.80^{\mathrm{n}}\end{array}$ & $23.4^{\mathrm{k}}, 21.8^{1}, 5.04^{\circ}$ \\
\hline Naproxen & $120^{\mathrm{d}}, 59^{\mathrm{h}}, 43^{\mathrm{h}}, 58^{\mathrm{h}}$ & $11^{\mathrm{h}}, 28^{\mathrm{h}}$ \\
\hline Diclofenac & $312^{\mathrm{d}}, 360^{\mathrm{e}}$ & \\
\hline Codeine & $\begin{array}{l}160^{\mathrm{a}}, 79^{\mathrm{b}}, 182^{\mathrm{k}}, 80.2^{\mathrm{l}}, \\
214^{\mathrm{m}}, 62.5^{\mathrm{n}}, 242^{\circ}\end{array}$ & $\begin{array}{l}82^{\mathrm{a}}, 25^{\mathrm{b}}, 44.2^{1}, 208^{\mathrm{m}}, \\
37.2^{\mathrm{n}}, 38.0^{\circ}\end{array}$ \\
\hline Oxycodone & $4.0^{\mathrm{k}}, 21.6^{\mathrm{n}}$ & \\
\hline Mefenamic acid & $1100^{\mathrm{a}}, 1100^{\mathrm{b}}$ & $570^{\mathrm{a}}, 440^{\mathrm{b}}$ \\
\hline \multicolumn{3}{|l|}{ Antihistamine } \\
\hline Diphenhydramine & $\begin{array}{l}97^{\mathrm{a}}, 44^{\mathrm{b}}, 83.0^{\mathrm{k}}, 34.8^{\mathrm{l}} \\
112^{\mathrm{m}}, 144^{\mathrm{n}}, 130^{\circ}\end{array}$ & $\begin{array}{l}32^{\mathrm{a}}, 15^{\mathrm{b}}, 35.0^{\mathrm{k}}, 24.6^{1}, \\
108^{\mathrm{m}}, 52.4^{\mathrm{n}}, 91.2^{\circ}\end{array}$ \\
\hline DPMA & $50.6^{\mathrm{n}}$ & $32.0^{\mathrm{k}}, 23.2^{1}, 25.4^{\circ}$ \\
\hline Ranitidine & $1800^{\mathrm{i}}$ & \\
\hline \multicolumn{3}{|l|}{ Antiplatelet } \\
\hline Clopidogrel & $\begin{array}{l}130^{\mathrm{a}}, 130^{\mathrm{b}}, 34.0^{\mathrm{k}}, 4.78^{\mathrm{l}}, \\
172^{\mathrm{m}}, 5.08^{\mathrm{n}}, 258^{\circ}\end{array}$ & $\begin{array}{l}54^{\mathrm{b}}, 2.52^{\mathrm{k}}, 1.95^{\mathrm{l}} \\
191^{\mathrm{m}}, 8.84^{\circ}\end{array}$ \\
\hline $\begin{array}{l}\text { Clopidogrel carboxylic } \\
\text { acid }\end{array}$ & $\begin{array}{l}200^{\mathrm{a}}, 300^{\mathrm{b}}, 202^{\mathrm{k}}, 175^{1} \\
658^{\mathrm{m}}, 173^{\mathrm{n}}, 712^{\mathrm{o}}\end{array}$ & $\begin{array}{l}430^{\mathrm{a}}, 460^{\mathrm{b}}, 149^{\mathrm{k}}, \\
95.8^{1}, 1540^{\mathrm{m}}, 84.0^{\mathrm{n}}, \\
1480^{\circ}\end{array}$ \\
\hline \multicolumn{3}{|c|}{ Antihypercholesterolemic } \\
\hline Atorvastatin & $410^{\mathrm{a}}, 380^{\mathrm{b}}$ & $280^{\mathrm{a}}, 340^{\mathrm{b}}$ \\
\hline \multicolumn{3}{|l|}{ UV-filter } \\
\hline Oxybenzone & $5^{\mathrm{a}}, 39^{\mathrm{b}}, 70.8^{\mathrm{n}}, 85.6^{\mathrm{o}}$ & $\begin{array}{l}7.0^{\mathrm{a}}, 1.1^{\mathrm{b}}, 41.2^{\mathrm{k}}, \\
37.0^{\mathrm{n}}\end{array}$ \\
\hline Benzophenone & $3960^{f}$ & $1500^{f}$ \\
\hline \multicolumn{3}{|l|}{ Illicit drugs } \\
\hline Cocaine & $32.4^{\mathrm{m}}$ & $17.0^{\mathrm{k}}, 55.6^{\mathrm{m}}$ \\
\hline Benzoylecgonine & $\begin{array}{l}34.2^{\mathrm{k}}, 17.8^{\mathrm{l}}, 27.8^{\mathrm{m}}, 12.5^{\mathrm{n}} \\
55.0^{\circ}\end{array}$ & $\begin{array}{l}33.4^{\mathrm{k}}, 14.9^{1}, 33.8^{\mathrm{m}} \\
23.2^{\mathrm{n}}, 41.6^{\mathrm{o}}\end{array}$ \\
\hline Norcocaine & $\begin{array}{l}36.4^{\mathrm{k}}, 11.2^{1}, 15.0^{\mathrm{m}}, 6.44^{\mathrm{n}} \\
28.0^{\circ}\end{array}$ & $\begin{array}{l}34.4^{\mathrm{k}}, 19.0^{\mathrm{l}}, 33.8^{\mathrm{m}}, \\
29.8^{\mathrm{n}}, 20.0^{\circ}\end{array}$ \\
\hline Morphine & $189^{\mathrm{k}}, 148^{\mathrm{m}}, 141^{\circ}$ & \\
\hline$E D D P$ & $10.4^{1}, 5.16^{\mathrm{m}}$ & $10.8^{1}, 2.58^{\mathrm{n}}$ \\
\hline Methamphetamine & $\begin{array}{l}10.9^{\mathrm{k}}, 153^{\mathrm{l}}, 42.4^{\mathrm{m}}, 386^{\mathrm{n}} \\
10.4^{\mathrm{o}}\end{array}$ & $\begin{array}{l}498^{\mathrm{k}}, 304^{1}, 462^{\mathrm{n}}, \\
310^{\circ}\end{array}$ \\
\hline Amphetamine & $\begin{array}{l}238^{\mathrm{k}}, 286^{\mathrm{l}}, 760^{\mathrm{m}}, 4300^{\mathrm{n}}, \\
4720^{\circ}\end{array}$ & $\begin{array}{l}2240^{\mathrm{k}}, 700^{\mathrm{l}}, 558^{\mathrm{m}}, \\
660^{\circ}\end{array}$ \\
\hline MDA & $440^{\mathrm{k}}, 59.2^{1}, 216^{\mathrm{n}}, 98.0^{\circ}$ & $1150^{\mathrm{m}}, 114^{\mathrm{n}}$ \\
\hline MDMA & $23.0^{\mathrm{m}}$ & $21.8^{\mathrm{k}}$ \\
\hline \multicolumn{3}{|l|}{ Stimulant } \\
\hline Caffeine & $\begin{array}{l}61000^{\mathrm{a}}, 30000^{\mathrm{b}}, 102840^{\mathrm{f}}, \\
29600^{\mathrm{i}}, 18400^{\mathrm{j}}, 22.8^{\mathrm{k}} \\
16.0^{1}, 42500^{\mathrm{m}}, 38100^{\mathrm{n}} \\
60500^{\circ}\end{array}$ & $\begin{array}{l}1100^{\mathrm{a}}, 3400^{\mathrm{b}}, 46700^{\mathrm{f}}, \\
19.0^{\mathrm{k}}, 1067^{1}, 51700^{\mathrm{m}}, \\
389^{\circ}\end{array}$ \\
\hline Paraxanthine & $19000^{\mathrm{a}}, 7400^{\mathrm{b}}$ & $760^{\mathrm{a}}, 1500^{\mathrm{b}}$ \\
\hline \multicolumn{3}{|l|}{ Artificial sweeteners } \\
\hline Saccharin & $\begin{array}{l}369000^{\mathrm{k}}, 143000^{1} \\
315000^{\mathrm{m}}, 389000^{\mathrm{n}}, \\
299000^{\circ}\end{array}$ & $\begin{array}{l}6020^{1}, 379000^{\mathrm{m}} \\
21100^{\circ}\end{array}$ \\
\hline Sucralose & $\begin{array}{l}618^{\mathrm{k}}, 1060^{1}, 1820^{\mathrm{m}}, 384^{\mathrm{n}}, \\
3420^{\circ}\end{array}$ & $\begin{array}{l}922^{\mathrm{k}}, 1340^{1}, 2440^{\mathrm{m}}, \\
1540^{\mathrm{n}}, 2460^{\circ}\end{array}$ \\
\hline Acesulfame & $57.6^{\mathrm{l}}, 72.8^{\mathrm{m}}, 62.4^{\mathrm{n}}, 85.4^{\circ}$ & $\begin{array}{l}8.28^{\mathrm{k}}, 51.2^{1}, 389^{\mathrm{m}} \\
63.8^{\mathrm{n}}, 157^{\circ}\end{array}$ \\
\hline Cyclamate & $\begin{array}{l}86.2^{1}, 8180^{\mathrm{m}}, 3920^{\mathrm{n}}, \\
5120^{\circ}\end{array}$ & $\begin{array}{l}12.9^{\mathrm{k}}, 1220^{\mathrm{m}}, 1670^{\mathrm{n}}, \\
592^{\circ}\end{array}$ \\
\hline
\end{tabular}

NR: not-reported; pharmaceutical metabolites are italicized

DPMA: 2-(diphenylmethoxy) acetic acid; EDDP: (2-ethylidene-1,5-dimethy-3,3-diphenylpyrrolidine); MDA: (3,4-methylenedioxyamphetamine); MDMA: (3,4-methylenedioxymethamphetamine).

a In Udupi WTP, Karnataka, inflow: 7.5 MLD, serve 150,000 people, anaerobic sludge treatment, grab samples, sampled for consecutive seven days in a week (Subedi et al., 2017)

${ }^{\mathrm{b}}$ In Mangalore WTP, Karnataka, inflow: 12 MLD, serve 450,000 people, anaerobic sludge treatment and upflow anaerobic sludge blanket digestor, grab samples, sampled for consecutive seven days in a week (Subedi et al., 2017)

c In Okhla WTP, Delhi, inflow: 110 MLD, anaerobic sludge treatment, grab samples, sampled for five days (Mutiyar and Mittal, 2014)

${ }^{\mathrm{d}}$ In a WTP in Ghaziabad, Northern India, $24 \mathrm{~h}$ composite samples (from every 4-h grab samples), sampled once (Singh et al., 2014)

e In a WTP in Lucknow, Utter Pradesh, 24 h composite samples (from every 4-h grab samples), sampled once (Singh et al., 2014)

${ }^{\mathrm{f}}$ In a WTP in Nagpur, inflow: 80 MLD, primary and secondary anaerobic sludge treatment, grab samples, three sampling events in summer (Archana et al., 2016)

${ }^{\mathrm{g}}$ In a WTP in Southern India, inflow: 1.7 MLD, serve $~ 15,000$ people, anaerobic sludge treatment, grab samples, a sampling event in each of three seasons (concentrations were reported in the range) (Akiba et al., 2015)

${ }^{\mathrm{h}}$ In a WTP in Southern India, inflow: 2.0 MLD, serve 9000 people, aeration sludge treatment (cost-effective), grab samples, a sampling event in each of three seasons (Prabhasankar et al., 2016)

${ }^{\mathrm{i}}$ In a WTP in Western India, inflow: 46 MLD, facultative aerated lagoon based treatment, $24 \mathrm{~h}$ composite samples, a sampling event in each of three seasons (Mohapatra et al., 2016)

${ }^{\mathrm{j}}$ In a WTP in Western India, inflow: 60 MLD, cyclic anaerobic sludge treatment, $24 \mathrm{~h}$ composite samples, a sampling event in each of three seasons (Mohapatra et al., 2016)

${ }^{\mathrm{k}}$ In Saidpur WTP in Bihar (Northern India), inflow: 19 MLD, serve 350,000 people, anaerobic sludge treatment, grab samples, sampled once (Subedi et al., 2015a)

${ }^{1}$ In Beur WTP in Bihar (Northern India), inflow: 20.9 MLD, serve 275,000 people, anaerobic sludge treatment, grab samples, sampled once (Subedi et al., 2015a)

${ }^{\mathrm{m}}$ In Coimbatore WTP in Tamil Nadu (Southern India), inflow: 22.5 MLD, serve 350,000 people, anaerobic sludge treatment, grab samples, sampled once (Subedi et al., 2015a)

${ }^{\mathrm{n}}$ In Udupi WTP in Karnataka, inflow: 2.0 MLD, serve 10,000 people, anaerobic sludge treatment, grab samples, sampled once (Subedi et al., 2015a)

${ }^{\circ}$ In Manipal WTP in Karnataka, inflow: 2.0 MLD, serve 12,000 people, anaerobic sludge treatment, grab samples, sampled once (Subedi et al., 2015a)

pharmaceuticals production facilities (Fick et al., 2009; Larsson et al., 2007). Studies conducted at the PETL (Patancheru Enviro Tech Limited) WTP near Hyderabad, that received 1.5 MLD effluents from 90 bulk drug manufacturers in the vicinity in Patancheru, found the highest levels of pharmaceuticals ever reported in wastewater from elsewhere in the world.

The maximum reported concentrations of ciprofloxacin in wastewater were $0.6 \mu \mathrm{g} / \mathrm{L}$ across 6 WTPs in Canada (Guerra et al., 2014), $1.4 \mu \mathrm{g} / \mathrm{L}$ in Holland (Batt et al., 2007), $1.4 \mu \mathrm{g} / \mathrm{L}$ in Portugal (Santos et al., 2013), $3.7 \mu \mathrm{g} / \mathrm{L}$ in Italy (Verlicchi et al., 2012), and $6.9 \mu \mathrm{g} / \mathrm{L}$ in Australia (Pal et al., 2010). The concentration of ciprofloxacin reported by Larsson et al. (2007) was $\sim 4500$ times higher than the next highest reported (Australia). Ciprofloxacin is primarily prescribed for the treatment of seasonal diseases such as bronchitis, pneumonia, sinusitis, and is one of the most commonly prescribed drugs across the world (Coutu et al., 2013). However, ciprofloxacin levels reported from a WTP treating effluent from PETL may not represent an average level of ciprofloxacin from Indian WTPs that treat predominantly the domestic sewage. A revisit to the WTP after two years by Fick et al. (2009) showed that the concentrations of all pharmaceuticals, except cetirizine, had reduced considerably (Table 2).

\subsubsection{WTPs receiving domestic effluents in Northern India}

Carbamazepine (a psychoactive), atenolol (antihypertensive), triclocarban and triclosan (antimicrobials), trimethoprim and sulfamethoxazole (antibacterials), ibuprofen and acetaminophen (analgesics), and caffeine (stimulant) are the most commonly detected at higher concentrations in wastewater from Indian WTPs that treat predominantly the domestic sewage (Table 1). Mutiyar and Mittal (2013a) studied the fate of amoxicillin in a domestic WTP (Vasantkunj) that treats wastewater with an extended aeration technique in Delhi, 
Table 2

Comparison of pharmaceutical concentrations in the PETL WTP during 2007 and 2009

\begin{tabular}{|c|c|c|c|c|c|c|c|c|c|c|}
\hline \multirow[t]{2}{*}{ Year } & \multicolumn{9}{|c|}{ Pharmaceuticals concentrations $(\mu \mathrm{g} / \mathrm{L})$} & \multirow[t]{2}{*}{ References } \\
\hline & CIP & CET & METP & ENRO & CIT & NOR & LOM & ENO & OFL & \\
\hline 2007 & 31,000 & 1,400 & 950 & 900 & 840 & 420 & 300 & 300 & 160 & Larsson et al. 2007 \\
\hline 2009 & 14,000 & 2,100 & 4 & 210 & 430 & 25 & 8 & ND & 55 & Fick et al. 2009 \\
\hline
\end{tabular}

ND, not detected; CIP, ciprofloxacin; CET, cetirizine; METP, metoprolol; ENRO, enrofloxacin; CIT, citalopram; NOR, norfloxacin; LOM, lomefloxacin; ENO, enoxacin; OFL, ofloxacin

and found up to $172.6 \mathrm{ng} / \mathrm{L}$ in influent and $62.5 \mathrm{ng} / \mathrm{L}$ of amoxicillin at the WTP outlet. Matsuo et al. (2011) found 100-2000 ng/L levels of amoxicillin in a WTP that treats wastewater with an activated sludgebased biological treatment process in Japan. However, amoxicillin was not detected in wastewater from 96 WTPs involving the diverse treatment processes including activated sludge and ozonation in a European Union-wide monitoring survey (Loos et al., 2013). Mutiyar and Mittal (2013a) attribute the higher concentration of amoxicillin in the Vasantkunj WTP to that being sold as an over-the-counter drug in India, whereas amoxicillin is a prescription antibiotic in Japan and Europe. Other studies involving activated sludge in Australia reported the similar concentration of amoxicillin in influent (Watkinson et al., 2007), whereas 20 times higher concentration in wastewater effluent in a WTP involving an advance biological treatment in Hong-Kong (Minh et al., 2009). The removal efficiency of amoxicillin in WTPs varies depending on the mass loading, type of treatment adopted, the size of population served, their socio-economic status, and geographic location (Spongberg and Witter, 2008).

Ciprofloxacin concentration in the outlet at Okhla WTP, Delhi (Mutiyar and Mittal, 2014) is 2.5 times higher than that observed in WTP outlets of Australia (Al-Rifai et al., 2007), 5 times higher than the WTP outlets in Italy (Verlicchi et al., 2012) and at least 15 times higher than the values in the WTP outlets of other countries given in Fig. 2. The ciprofloxacin concentration in the discharge of Okhla WTP exceeds the predicted no-effect concentration (PNEC $=0.005 \mu \mathrm{g} / \mathrm{L}$ ) (Deo and Halden, 2013). Studies have shown that ciprofloxacin concentrations ranging from 0.012 to $1.5 \mathrm{mg} / \mathrm{L}$ resulted in a decline in the genetic diversity of algal communities (Wilson et al., 2003; Kaplan, 2013). Therefore, further research is inevitable for the determination of exposure levels of ciprofloxacin and relevant fluoroquinolones, and their effects in the aquatic environment.
The concentration of one of the recalcitrant antihypertensives, metoprolol, in Okhla WTP is approximately 4 times higher than in wastewater effluents in Germany (Wick et al., 2009) and 8 times higher than that detected in the USA. (Kostich et al., 2014). Typically, metoprolol transformation/degradation ranges from $0-30 \%$ (Oulton et al., 2010; Miege et al., 2009; Mutiyar and Mittal (2014) also found the concentrations of ampicillin at $17.7 \mu \mathrm{g} / \mathrm{L}$, gatifloxacin at $3.7 \mu \mathrm{g} / \mathrm{L}$, sparfloxacin at $0.5 \mu \mathrm{g} / \mathrm{L}$ and cefuroxime at $0.6 \mu \mathrm{g} / \mathrm{L}$ in the Okhla WTP effluent.

Subedi et al. (2015a) reported 43 pharmaceuticals and their 13 metabolites including psychoactives, illicit drugs, and artificial sweeteners, in five WTPs that treat domestic sewage in India. The amphetamine was measured at the mean concentration of 4.30 and $4.72 \mu \mathrm{g} / \mathrm{L}$ in two WTPs, the highest ever reported concentration in wastewater. Similarly, saccharin was the most abundant artificial sweetener with a mean concentration of $303 \mu \mathrm{g} / \mathrm{L}$ in five WTPs (Subedi et al., 2015a). Triclocarban (an antimicrobial), carbamazepine (antipsychoactive), amphetamine (illicit drug), and saccharin (artificial sweetener) were annually discharged at $2.55-252 \mathrm{~kg}$ from a WTP with an average flow rate of 20.7 MLD and serving a population of 325,000 people in India.

\subsubsection{WTPs receiving domestic effluents in Southern India}

The concentration of ofloxacin found in a WTP outlet in Southern India (Akiba et al., 2015) was about 3.2 times lower than in the wastewater effluents from China ( $\mathrm{Bu}$ et al., 2013) (Fig. 2). The concentration of sulfamethoxazole in wastewater effluent from South India were $0.23 \mu \mathrm{g} / \mathrm{L}$ (Subedi et al., 2015a), $0.63 \mu \mathrm{g} / \mathrm{L}$ (Akiba et al., 2015) and $1.02 \mu \mathrm{g} / \mathrm{L}$ (Prabhasankar et al., 2016). The potential sequential microbial transformation during anaerobic sludge treatment in the WTPs studied by Subedi et al. (2015a) and Akiba et al. (2015) may explain the lower concentration of sulfamethoxazole than in WTP

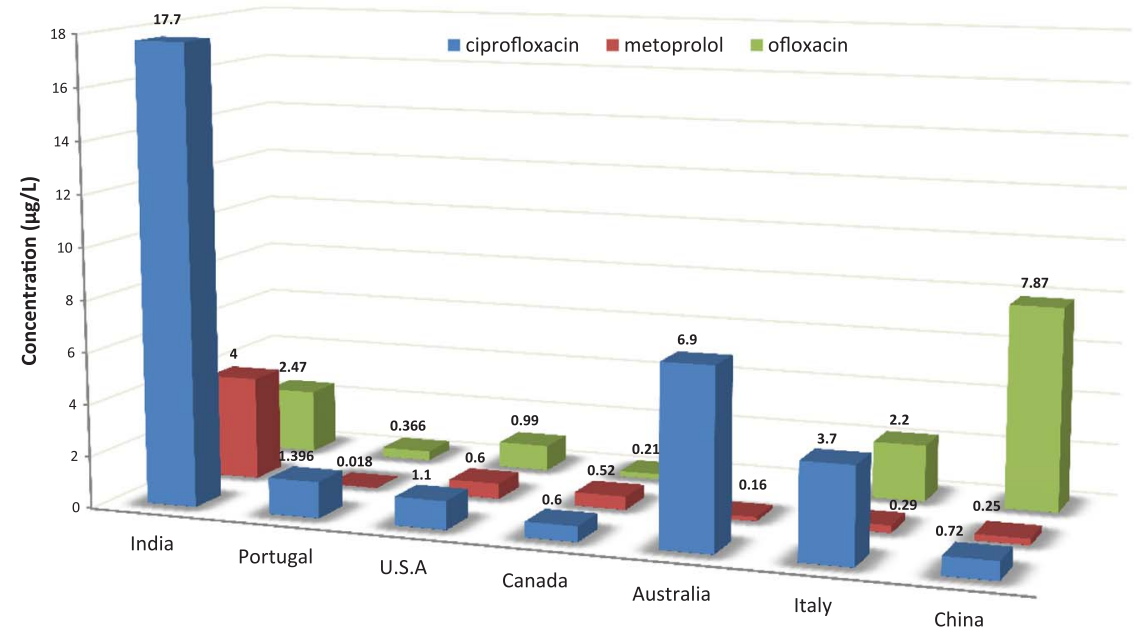

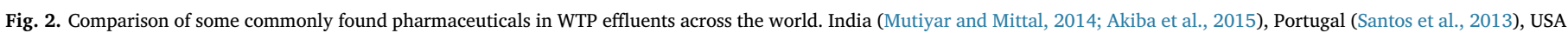

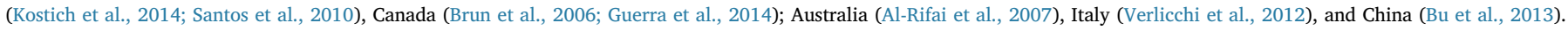


studied by Prabhasankar et al. (2016) that treats wastewater with an aeration sludge treatment (cost-effective and less labour-intensive wastewater treatment technique). The average concentration of sulfamethoxazole in the above WTPs were similar to the concentrations obtained in a WTP outlet in NW Spain (Carballa et al., 2004), while 2.7 times lower than the average for Europe and Canada $(1.7 \mu \mathrm{g} / \mathrm{L}$ for Europe; Loos et al., 2013 and 1.8 g/L for Canada; Guerra et al., 2014). However, the concentration of SMX in the Indian WTP effluent was two to four times higher than the WTP effluent in South Korea (Behera et al., 2011) and a WTP in Ohio, USA (Spongberg and Witter, 2008).

Subedi et al. (2017) compared the mass loading and environmental discharge of select psychoactives, antihypertensives, and antibiotics in two WTPs in Southern India with that in wastewater from WTPs in the USA. The mass loading $(\mathrm{mg} / \mathrm{d} / 1000$ people) and environmental discharge (mg/d/1000 people) of most of the studied pharmaceuticals in the USA were found higher than in India, which may indicate the different usage pattern of drugs.

\subsubsection{WTPs receiving hospital effluents}

Hospital effluents also act as point sources of pharmaceutical pollution in the water bodies. Concentrations of pharmaceuticals in hospital effluents are generally higher than in the domestic WTP effluents (Kovalova et al., 2013). Two studies have reported the concentrations of pharmaceuticals in hospital effluents in India (Diwan et al., 2009, 2010; Akiba et al., 2015). Diwan et al. (2009, 2010) carried out a study on antibiotics in the effluents of two hospitals in Ujjain (central India): the Ujjain Charitable Trust Hospital (UCTH) and Chandrikaben Rashmikant Gardi Hospital (CRGH). Effluents from UCTH contained $73 \mu \mathrm{g} / \mathrm{L}$ of ofloxacin, $81 \mu \mathrm{g} / \mathrm{L}$ of levofloxacin and $60 \mu \mathrm{g} / \mathrm{l}$ of ceftriaxone. Effluents from CRGH contained $237 \mu \mathrm{g} / \mathrm{L}$ of ciprofloxacin, $88 \mu \mathrm{g} / \mathrm{L}$ of tinidazole, $81 \mu \mathrm{g} / \mathrm{L}$ of sulfamethoxazole and $23 \mu \mathrm{g} / \mathrm{L}$ of norfloxacin. Metronidazole was found at lower concentration $(3.8 \mu \mathrm{g} / \mathrm{L})$, while amoxicillin and erythromycin were not detected in either of the hospital effluents. Akiba et al. (2015) analyzed wastewater from two WTPs in Southern India that received the hospital effluents; the first WTP exclusively treating hospital wastewater and the second WTP treating both, hospital effluents and domestic sewage. The WTP that received both the hospital and domestic effluents had higher concentrations of SMX (13 times), trimethoprim (6 times) and ofloxacin (5 times) in its outlet than the WTP that received only hospital effluents. Studies carried out by Santos et al. (2013) on hospital effluents in Coimbra (Portugal) showed values similar to those in South India. Verlicchi et al. (2012) studied the effluents from two hospitals in Italy, which were compared with the hospital effluents in India and Portugal (Fig. 3). It is evident from the figure that ciprofloxacin in the hospital effluent in India is about 10 times higher than in Italy and five times higher than in Portugal. The concentration of sulfamethoxazole is also about ten times higher than the corresponding concentrations in Italy and Portugal, while that of ofloxacin is found to be almost two times that in Italy and Portugal. However, the WTP in Portugal shows a higher concentration of metronidazole and erythromycin than in India and Italy. Doxycycline was found in similar concentrations in hospital effluents from India and Italy. The large difference in the concentrations of pharmaceuticals between the effluents in these countries could be attributed to the functioning of the treatment process, the consumption patterns, the population, and the method of disposal of expired pharmaceutical compounds. The comparison could have limitations based on the time of sample collection and the type of samples, the treatment capacity of the plant and the differing compositions of the hospital effluent between these countries.

\subsection{Rivers and Lakes}

Sewage originating from the WTPs is the major source of pharmaceuticals in natural water bodies, followed by agricultural discharge and direct discharge (Li et al., 2014). Eight studies have been carried out on the pharmaceutical concentrations in Indian rivers (Fick et al., 2009; Kristiansson et al., 2011; Mutiyar and Mittal, 2014; Ramaswamy et al., 2011; Shanmugam et al., 2013; Iyanee et al., 2013; Archana et al., 2016; Subedi et al., 2015a). All the studies have confirmed the presence of pharmaceuticals in the concerned rivers. The effluents from PETL discharge into the Isakavagu-Nakkavagu streams, which eventually flow into the Godavari River. Pharmaceuticals in the river or lake adsorb onto the soil/sediments, dilute, and undergo biological and/or photochemical transformations (Onesios et al., 2008). The pharmaceutical concentrations were significantly decreased when measured $30 \mathrm{~km}$ downstream of the PETL as compared to that at the PETL outlet: metoprolol (4 times), ofloxacin (9 times), cetirizine (22 times), citalopram (86 times), ciprofloxacin (1400 times), and enrofloxacin (3281 times) (Fick et al., 2009; Kristiansson et al., 2011). Subedi et al. (2015a) reported 35 pharmaceuticals and 10 metabolites in open sewage channels in residential areas. The Cooum River that flows through the Chennai metropolitan city (population: 8.9 million) found to be contaminated with triclocarban $(6.18 \mu \mathrm{g} / \mathrm{L})$, ibuprofen $(2.32 \mu \mathrm{g} /$ $\mathrm{L})$, a metabolite of antiplatelet carboxylic acid $(1.37 \mu \mathrm{g} / \mathrm{L})$, atenolol $(3.18 \mu \mathrm{g} / \mathrm{L})$, and amphetamine $(0.984 \mu \mathrm{g} / \mathrm{L})$ (Subedi et al., 2015a).

Although there is a reduction of more than $95 \%$ in their concentration in the rivers, traces of these pharmaceuticals and their transformation products continue to remain in the water bodies, leading to subtle, but long-term, changes in the aquatic environment (Long et al., 2013). Mutiyar and Mittal (2014) found ampicillin, ciprofloxacin, gatifloxacin, sparfloxacin and cefuroxime in the Yamuna River at $13.8 \mu \mathrm{g} / \mathrm{L}, 1.4 \mu \mathrm{g} /$ $\mathrm{L}, 0.48 \mu \mathrm{g} / \mathrm{L}, 2.1 \mu \mathrm{g} / \mathrm{L}$ and $1.7 \mu \mathrm{g} / \mathrm{L}$, respectively. This is $\sim 1000$ times

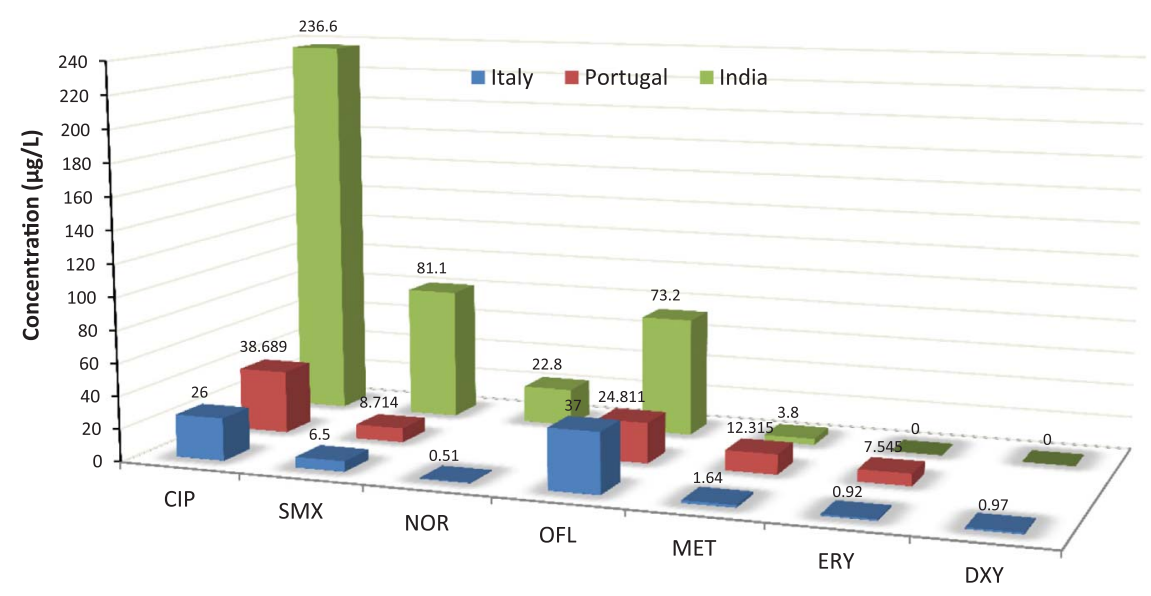

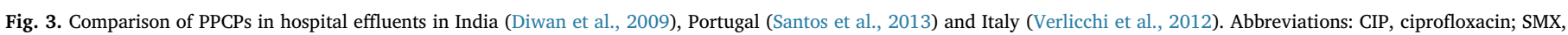
sulfamethoxazole; NOR, norfloxacin; OFL, ofloxacin; MET, metronidazole; ERY, erythromycin; DXY, doxycycline. 
lower than the concentration of pharmaceuticals in the IsakavaguNakkavagu stream samples collected downstream of PETL. Ramaswamy et al. (2011) detected $13.0 \mathrm{ng} / \mathrm{L}$ of carbamazepine in the Kaveri River and $139 \mathrm{ng} / \mathrm{L}$ of triclosan in the Bhavani River, a tributary of Kaveri. Shanmugam et al. (2013) observed the presence of NSAIDs including naproxen, diclofenac, ibuprofen, ketoprofen, and acetylsalicylic acid up to $0.66 \mu \mathrm{g} / \mathrm{L}$ in the Kaveri, Vellar, and Tamiraparani Rivers. Iyanee et al. (2013) observed seasonal variation in the concentration of sulfamethoxazole (monsoon: $0.9 \mu \mathrm{g} / \mathrm{L}$ and post-monsoon: $0.16 \mu \mathrm{g} / \mathrm{L}$ ) in the Kaveri and Vrishabhavathi (a tributary of Kaveri) Rivers in India. They suggested that the high levels of sulfamethoxazole during the monsoon could be associated with the high amount of runoff from agricultural lands in the surrounding areas.

In addition to erythromycin, chloramphenicol, and trimethoprim, multidrug-resistant pathogenic bacteria were found in the Byramangala tank, fed by the Vrishabavathi River, which resists multiple antibiotics prescribed and consumed in India (Iyanee et al., 2013). Kristiansson et al. (2011) detected very high levels of several classes of resistant genes and elements of horizontal gene transfer (integrons, transposons, and plasmids) in a river sediment in India, that received effluents from a WTP serving 90 drug production units near Hyderabad.

Concentrations of pharmaceuticals determined in rivers in India were compared with those in China, that are equally stressed owing to the comparable anthropogenic impact and their status, as the fastest rising economies in the third world (Fig. 4). Based on the recent reports on pharmaceutical residues in rivers from China (Bu et al., 2013; Zou et al., 2011) and India (Shanmugam et al., 2013; Iyanee et al., 2013; Fick et al., 2009), ciprofloxacin, enoxacin, gatifloxacin, and ketoprofen levels in the water bodies in India are much higher than those in China. This can reflect the different drug consumption patterns in India and China; for example, $64 \%$ of Indians purchase pharmaceuticals without a prescription, solely based on peer suggestions and prior experiences (Mutiyar and Mittal, 2013b). China's water bodies, on the other hand, have higher concentrations of erythromycin, naproxen, ibuprofen, diclofenac and enrofloxacin. This could be due to the differences in the health issues and climatic conditions between the two countries. The concentrations of sulfamethoxazole and ofloxacin exhibit similar patterns in the rivers in India and China. Metoprolol was observed in Ishkavagu and Nakavagu rivers in three of the 5 sampling locations both upsteam and downstream of the PETL discharge outlet. Their presence could be from domestic sewage (upstream) and PETL (downstream) in the river.

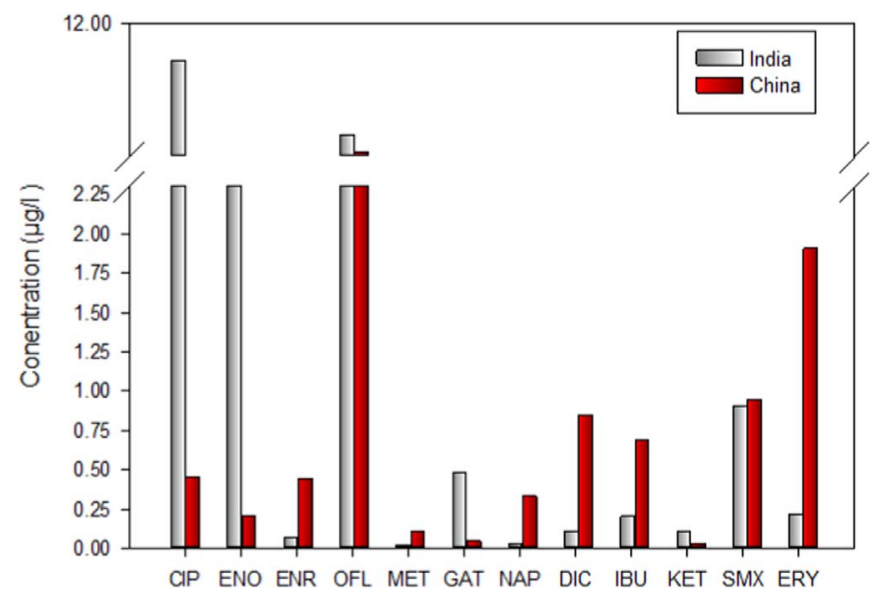

Fig. 4. Comparison of PPCP concentrations in Indian rivers (Fick et al., 2009; Mutiyar and Mittal, 2014; Shanmugam et al., 2013; Iyanee et al., 2013) and Chinese rivers (Bu et al., 2013). CIP: ciprofloxacin, ENO: enoxacin, ENR: enrofloxacin, OFL: ofloxacin, MET: metoprolol, GAT: gatifloxacin, NAP: naproxen, DIC: diclofenac, IBU: ibuprofen, KET: ketoprofen, SMX: sulfamethoxazole, ERY: erythromycin.

\subsection{Groundwater}

A considerable amount of data exists on pharmaceutical wastes in surface water; yet, literature demonstrating the pharmaceutical contamination of groundwater is relatively less (Wolf et al., 2012; Stuart et al., 2012). Fewer studies of pharmaceutical contamination in groundwater might have been resulted from the analytical challenges associated with the detection of the lower level of pharmaceutical contaminants in matrix-complex ground water than in surface water. Direct pathways of pharmaceutical contamination to the groundwater include disposal of sewage effluents on land, sewer leakage, landfill leachates, and sewage overflow during monsoon (Jones et al., 2002). Moreover, land-use activities such as agriculture can surrogate the presence of pharmaceuticals in groundwater (Fram and Belitz, 2011). In India, groundwater accounts for over $65 \%$ of irrigation and $85 \%$ of drinking water supplies (Globalwaterforum, 2012). However, only one study reported pharmaceuticals in groundwater in India (Fick et al., 2009). The wells around the PETL site have found to contain antibiotics (ciprofloxacin, trimethoprim, enoxacin, ofloxacin, norfloxacin), cetirizine, citalopram, and terbinafine ranging from $0.021 \mu \mathrm{g} / \mathrm{L}$ to $28 \mu \mathrm{g} / \mathrm{L}$. A nationwide survey of antibiotics in groundwater in China found 0.019-1.27 $\mu \mathrm{g} / \mathrm{L}$ of antibiotics (Ma et al., 2015). Overall, the maximum concentration of ciprofloxacin in ground water from India (Fick et al., 2009) was 90 and 43 times higher than in China (Ma et al., 2015) and Spain (Cabeza et al., 2012), respectively. Schaider et al. (2016) found 27 organic waste contaminants including antibiotics, psychoactives, analgesics, and antihypercholesterolemics upto $62 \mathrm{ng} / \mathrm{L}$ in 20 domestic wells from Cape Cod, Massachusetts, USA.

There is a shortage of supply and demand for the centralized sewage treatment in India, with $\sim 30 \%$ of the sewage produced is treated by municipal WTPs (Subedi et al., 2015a, Subedi et al., 2017). Therefore, the majority of Indian households primarily rely on the on-site septic systems for the treatment of domestic sewage or directly discharge through straight-pipes into the surface/ground water and soil. The pharmaceutical contaminants can percolate/infiltrate through the vadose region and potentially contaminate the underlying groundwater and nearby surface water (Subedi et al., 2015b; Verstraeten et al., 2005). Therefore, it is critical to comprehend the fate of pharmaceutical contaminants from septic systems and the associated ecological problems, particularly in developing countries where the majority of the population is served by septic systems.

\subsection{Recommendations}

Most of the WTPs around the world are not designed for the complete removal of pharmaceutical contaminants because the extent of the ecological threats posed by PPCPs are vaguely understood (Luo et al., 2014). Owing to their occurrence at trace levels in the aquatic environment and a dearth of evidence of adverse effects on aquatic ecosystem and humans, pharmaceuticals are generally not considered a primary ecological threat, particularly in the developing countries such as India.

Most of the studies on pharmaceutical residues in wastewater from Indian WTPs are focussed on parent drugs; however, select metabolites of drugs are discharged at higher concentration into the environment than their parent analogues, and are physiologically active as their parent drugs (Subedi et al., 2014, 2015a). Therefore, it is important to include drug metabolites as target analytes to comprehend the overall residual levels and their effects in the environment. It is important to note that most of the fate studies of pharmaceuticals in Indian WTPs involve grab samples (Table 1 footnotes), that may result into the over or under-estimation of actual mass loads and environmental emission of drugs. Therefore, $24 \mathrm{~h}$ composite wastewater samples for at least a week-long sampling event in different seasons may provide authorities the overall accurate levels of residual drugs in the environment. Analytically, most of the fate studies of residual drugs in Indian WTPs 
have utilized external standard or internal standard method of quantification in wastewater, which is one of the most complex environmental matrices. Isotopic dilution and matrix-match method of quantification would provide more accurate and reproducible recoveries among fate studies across different WTPs. Moreover, the pharmaceuticals are found to accumulate in biological tissues in the aquatic ecosystem (Subedi et al.; 2012). More studies on bioaccumulation of drugs residues and their effect in indigenous aquatic organisms would provide significant information to authorities to scheme guidelines and proper implication.

Large-scale studies, therefore, are required in local and state strata to investigate the sources, overall fate, and the effects of pharmaceutical contaminants on the flora and fauna. Temporal studies may provide the subtle changes caused by these pharmaceuticals in the aquatic environment. Therefore, the research networks and capacity build-up among government and private institutions is important for the establishment of a robust analytical protocol. Ample research investment and the research fund are required to develop state-of-art analytical capacity, enhance public awareness on the proper use of used/unused drugs, and expand and update the conventional WTPs. In addition, regulatory agencies are important to define and implement proper guidelines on the maximum permissible limits for discharge into the aquatic environment from production facilities, hospitals, and municipal WTPs. Overall, a sustainable solution, one of the most important challenges of 21st century, could somehow address the pharmaceutical contamination and their effect in wildlife and humans.

\section{Conclusion}

Very few studies are reported on pharmaceutical contamination in water bodies in India despite it being one of the largest drug producers and consumers in the world. The environmental emission of pharmaceutical residues into the environment can be an imminent threat to the water resources in India. Wide-range of pharmaceutical residues derived from domestic use, hospitals, production facilities are reported in wastewater, rivers, and groundwater including psychoactives, antibiotics, analgesics, antihistamine, illicit drugs, and artificial sweeteners. Antibiotics (such as ciprofloxacin) in WTP receiving effluent from drug production as well as amphetamine (illicit drug) from a WTP treating domestic sewer are the highest ever reported from anywhere in the world. Domestic WTPs in India revealed that the concentrations of amoxicillin, ciprofloxacin, metoprolol and ofloxacin in the treated effluents were higher than in WTPs in Europe, Japan, and Australia. However, sulfamethoxazole from Indian WTPs is reported at similar levels as in Spain but lower than in Europe and Canada. The over-thecounter availability of wide-range of drugs in India could have resulted in the higher levels of drug residues in the environment in addition to a shortage of supply and demand of sewer treatment capacity, inefficient treatment, as well as the lack of treatment regulations and implications.

Very few studies on pharmaceutical residues in rivers (only seven studies in Yamuna, Kaveri, Vellar, Tamiraparani, Vrishabavathi, Godavari, and Cooum River) and only one study in open wells (groundwater) are reported. No study is reported on drug residues in septic discharge despite $>50 \%$ of Indian population is being served by on-site septic treatment systems. Overall, very few studies have reported the mass loading and environmental discharge incorporating pharmaceutical metabolites. There are no reports of pharmaceuticals in indigenous aquatic organisms to understand bioaccumulation and potential acute and chronic toxicity. This review provides the status of understanding on pharmaceutical residues in the aquatic ecosystem in India. This review provides important information for the stakeholders including regulatory agencies in India to establish the minimum permissible limits of pharmaceuticals in wastewater and spur research on cost-effective pharmaceutical removal strategies in the Indian WTPs.

\section{Acknowledgement}

The authors would like to thank Dr. T. M. A. Pai Endowment Chair in Earth Sciences awarded to KB, for the financial support and logistics. This work was also partially supported by the Japan Society for the Promotion of Science, a Grant-in-Aid for Scientific Research (A), 20122014 (24256004) to KSG.

\section{References}

Akiba, M., Senba, H., Otagiri, H., Prabhasankar, V., Taniyasu, S., Yamashita, N., Lee, K., Yamamoto, T., Tsutsui, T., Ian Joshua, D., Balakrishna, K., Bairy, I., Iwata, T., Kusumoto, M., Kannan, K., Guruge, K., 2015. Impact of wastewater from different sources on the prevalence of antimicrobial-resistant Escherichia coli in sewage treatment plants in South India. Ecotoxicol. Environ. Saf. 115, 203-208.

Al-Rifai, J., Gabelish, C., Schafer, A., 2007. Occurrence of pharmaceutically active and non-steroidal estrogenic compounds in three different wastewater recycling schemes in Australia. Chemosphere 69, 803-815.

Archana, G., Dhodapakar, R., Kumar, A., 2016. Offline solid-phase extraction for preconcentration of pharmaceuticals and personal care products in environmental water and their simultaneous determination using the reversed phase highperformance liquid chromatography method. Environ. Monit. Assess. 188, 512-522.

Anumol, T., Vijayanandan, A., Park, M., Philip, L., Snyder, S.A., 2016. Occurrence and fate of emerging trace organic chemicals in wastewater plants in Chennai, India. Environ. Int. 92-93, 33-42.

Batt, A., Kim, S., Aga, D., 2007. Comparison of the occurrence of antibiotics in four fullscale wastewater treatment plants with varying designs and operations. Chemosphere $68,428-435$.

Behera, S., Kim, H., Oh, J., Park, H., 2011. Occurrence and removal of antibiotics, hormones and several other pharmaceuticals in wastewater treatment plants of the largest industrial city of Korea. Sci. Total Environ. 409, 4351-4360.

Brun, G., Bernier, M., Losier, R., Doe, K., Jackman, P., Lee, H., 2006. Pharmaceutically active compounds in Atlantic Canadian sewage treatment plant effluents and receiving waters and potential for environmental effects as measured by acute and chronic aquatic toxicity. Environ. Toxicol. Chem. 25, 2163.

Bu, Q., Wang, B., Huang, J., Deng, S., Yu, G., 2013. Pharmaceuticals and personal care products in the aquatic environment in China: a review. J. Hazard. Mater. 262, 189-211.

Cabeza, Y., Candela, L., Ronen, D., Teijon, G., 2012. Monitoring the occurrence of emerging contaminants in treated wastewater and groundwater between 2008 and 2010. The Baix Llobregat (Barcelona, Spain). J. Hazard. Mater. 239-240, 32-39.

Carballa, M., Omil, F., Lema, J., Llompart, M., Garcia-Jares, C., Rodríguez, I., Gomez, M., Ternes, T., 2004. Behavior of pharmaceuticals, cosmetics and hormones in a sewage treatment plant. Water Res. 38, 2918-2926.

Chen, H., Li, X., Zhu, S., 2012. Occurrence and distribution of selected pharmaceuticals and personal care products in aquatic environments: a comparative study of regions in China with different urbanization levels. Environ. Sci. Pollut. Res. 19, 2381-2389.

Coutu, S., Wyrsch, V., Wynn, H., Rossi, L., Barry, D., 2013. Temporal dynamics of antibiotics in wastewater treatment plant influent. Sci. Total Environ. 458-460, 20-26.

Daughton, C., Ternes, T., 1999. Pharmaceuticals and personal care products in the environment: agents of subtle change? Environ. Health Perspect. 107, 907-938.

Deo, R., Halden, R., 2013. Pharmaceuticals in the built and natural water environment of the United States. Water 5, 1346-1365.

Diwan, V., Tamhankar, A.J., Aggarwal, M., Sen, S., Khandal, R.K., Stalsby- Lundborg, C., 2009. Detection of antibiotics in hospital effluents in India. Curr. Sci. 12, 1752-1755.

Diwan, V., Tamhankar, A., Khandal, R., Sen, S., Aggarwal, M., Marothi, Y., Iyer, R., Sundblad-Tonderski, K., Stalsby-Lundborg, C., 2010. Antibiotics and antibioticresistant bacteria in waters associated with a hospital in Ujjain, India. BMC Public Health 10, 414.

Fick, J., Soderstrom, H., Lindberg, R., Phan, C., Tysklind, M., Larsson, D., 2009. Contamination of surface, ground and drinking water from pharmaceutical production. Environ. Toxicol. Chem. 28, 2522.

Fram, M., Belitz, K., 2011. Occurrence and concentrations of pharmaceutical compounds in groundwater used for public drinking-water supply in California. Sci. Total Environ. 409, 3409-3417.

Globalwaterforum.org 2012 Global Water Forum: India's groundwater crisis. http:// www.globalwaterforum.org/2012/07/30/indias-groundwater-crisis/.

Guerra, P., Kim, M., Shah, A., Alaee, M., Smyth, S., 2014. Occurrence and fate of antibiotic, analgesic/anti-inflammatory, and antifungal compounds in five wastewater treatment processes. Sci. Total Environ. 473-474, 235-243.

Hirsch, R., Ternes, T., Haberer, K., Kratz, K., 1999. Occurrence of antibiotics in the aquatic environment. Sci. Total Environ. 225, 109-118.

Iyanee F. S., Simamura K., Prabhasankar V. P., Taniyasu S., Tsuruta M., Balakrishna K., Yamashita N., Guruge K. S., Akiba M., Joshua D. I., Kannan K., 2013. Occurrence of antibiotics in river water: A case study of Vrishabhavathi River near Bangalore, India. 33rd International Symposium on Halogenated Persistent Organic Pollutants, DIOXIN 2013, 25-30 August 2013, Daegu, Korea

Jones, O., Voulvoulis, N., Lester, J., 2002. Aquatic environmental assessment of the top 25 English prescription pharmaceuticals. Water Res. 36, 5013-5022.

Kallummal M, Bugalya K., 2012. Trends in India's Trade in Pharmaceutical Sector: Some Insights. 1-97

Kaplan, S., 2013. Review: pharmacological pollution in water. Crit. Rev. Env. Sci. 
Technol. 43, 1116.

Kidd, K., Blanchfield, P., Mills, K., Palace, V., Evans, R., Lazorchak, J., Flick, R., 2007. Collapse of a fish population after exposure to a synthetic estrogen. Proc. Natl. Acad. Sci. USA 104, 8897-8901.

Klosterhaus, S.L., Grace, R., Hamilton, M.C., Yee, D., 2013. Method validation and reconnaissance of pharmaceuticals, personal care products, and alkyl phenols in surface waters, sediments, and mussels in an urban estuary. Environ. Int. 54, 92-99.

Kolpin, D., Furlong, E., Meyer, M., Thurman, E., Zaugg, S., Barber, L., Buxton, H., 2002. Pharmaceuticals, Hormones, and Other Organic Wastewater Contaminants in U.S. Streams, 1999-2000: a National Reconnaissance. Environ. Sci. Technol. 36, 1202-1211.

Kostich, M., Batt, A., Lazorchak, J., 2014. Concentrations of prioritized pharmaceuticals in effluents from 50 large wastewater treatment plants in the US and implications for risk estimation. Environ. Pollut. 184, 354-359.

Kovalova, L., Siegrist, H., von Gunten, U., Eugster, J., Hagenbuch, M., Wittmer, A., Moser, R., McArdell, C., 2013. Elimination of Micropollutants during Post-Treatment of Hospital Wastewater with Powdered Activated Carbon, Ozone, and UV. Environ. Sci. Technol. 47, 7899-7908.

KPMG International., 2006. The Indian Pharmaceutical Industry: Collaboration for Growth. 2-42

Kristiansson, E., Fick, J., Janzon, A., Grabic, R., Rutgersson, C., Weijdegard, B., Soderstrom, H., Larsson, D., 2011. Pyrosequencing of antibiotic-contaminated river sediments reveals high levels of resistance and gene transfer elements. PLoS One 6, e17038.

Kummerer, K., 2009. Antibiotics in the aquatic environment - A review - Part I. Chemosphere 75, 417-434.

Larsson, D., de Pedro, C., Paxeus, N., 2007. Effluent from drug manufacturers contains extremely high levels of pharmaceuticals. J. Hazard. Mater. 148, 751-755.

Li, Y., Zhu, G., Ng, W., Tan, S., 2014. A review on removing pharmaceutical contaminants from wastewater by constructed wetlands: design, performance, and mechanism. Sci. Total Environ. 468-469, 908-932.

Long, E., Dutch, M., Weakland, S., Chandramouli, B., Benskin, J., 2013. Quantification of pharmaceuticals, personal care products, and perfluoroalkyl substances in the marine sediments of Puget Sound, Washington, USA. Environ. Toxicol. Chem. 32, 1701-1710.

Loos, R., Carvalho, R., Antonio, D., Comero, S., Locoro, G., Tavazzi, S., Paracchini, B., Ghiani, M., Lettieri, T., Blaha, L., Jarosova, B., Voorspoels, S., Servaes, K., Haglund, P., Fick, J., Lindberg, R., Schwesig, D., Gawlik, B., 2013. EU-wide monitoring survey on emerging polar organic contaminants in wastewater treatment plant effluents. Water Res. 47, 6475-6487.

Luo, Y., Guo, W., Ngo, H.H., Nghiem, L.D., Hai, F.I., Zhang, J., Liang, S., Wang, X.C., 2014. A review on the occurrence of micro pollutants in the aquatic environment and their fate and removal during waste water treatment. Sci. Total Environ. 473-474, 619-641.

Matsuo, H., Sakamoto, H., Arizono, K., Shinohara, R., 2011. Behavior of pharmaceuticals in waste water treatment plant in Japan. Bull. Environ. Contam. Toxicol. 87, 31-35.

Miege, C., Choubert, J., Ribeiro, L., Eusebe, M., Coquery, M., 2009. Fate of pharmaceuticals and personal care products in wastewater treatment plants Conception of a database and first results. Environ. Pollut. 157, 1721-1726.

Minh, T., Leung, H., Loi, I., Chan, W., So, M., Mao, J., Choi, D., Lam, J., Zheng, G., Martin, M., Lee, J., Lam, P., Richardson, B., 2009. Antibiotics in the Hong Kong metropolitan area: Ubiquitous distribution and fate in Victoria Harbour. Mar. Pollut. Bull. 58, 1052-1062.

Mohapatra, S., Huang, C.H., Mukherji, S., Padhye, L.P., 2016. Occurrence and fate of pharmaceuticals in WWTPs in India and comparison with a similar study in the United States. Chemosphere 159, 526-535.

Mutiyar, P., Mittal, A., 2013a. Occurrences and fate of an antibiotic amoxicillin in extended aeration-based sewage treatment plant in Delhi, India: a case study of emerging pollutant. Desalin. Water Treat. 51, 6158-6164.

Mutiyar, P. and Mittal, A. 2013b. Pharmaceuticals and Personal Care Products (PPCPs) Residues in Water Environment of India: A Neglected but Sensitive Issue, 28th National Convention of Environmental Engineers and National Seminar on Hazardous Waste Management and Healthcare in India, March 9-10, Patna, India, Institute of Engineers. (https://www.researchgate.net/publication/261795740_ Pharmaceuticals_and_Personal_Care_Products_PPCPs_Residues_in_Water_ Environment_of_India_A_Neglected_but_Sensitive_Issue)

Mutiyar, P., Mittal, A., 2014. Occurrences and fate of selected human antibiotics in influents and effluents of sewage treatment plant and effluent-receiving river Yamuna in Delhi (India). Environ. Monit. Assess. 186, 541-557.

Onesios, K., Yu, J., Bouwer, E., 2008. Biodegradation and removal of pharmaceuticals and personal care products in treatment systems: a review. Biodegradation 20, 441-466.

Oulton, R., Kohn, T., Cwiertny, D., 2010. Pharmaceuticals and personal care products in effluent matrices: a survey of transformation and removal during wastewater treatment and implications for wastewater management. J. Environ. Monit. 12, 1956.

Pal, A., Gin, K., Lin, A., Reinhard, M., 2010. Impacts of emerging organic contaminants on freshwater resources: review of recent occurrences, sources, fate and effects. Sci. Total Environ. 408, 6062-6069.

Prabhasankar, V., Joshua, D., Balakrishna, K., Siddiqui, I., Taniyasu, S., Yamashita, N., Kannan, K., Akiba, M., Praveenkumarreddy, Y., Guruge, K., 2016. Removal rates of antibiotics in four sewage treatment plants in South India. Environ. Sci. Pollut. Res.
23, 8679-8685.

Ramaswamy, B., Shanmugam, G., Velu, G., Rengarajan, B., Larsson, D., 2011. GC-MS analysis and ecotoxicological risk assessment of triclosan, carbamazepine, and parabens in Indian rivers. J. Hazard. Mater. 186, 1586-1593.

Rehman, M., Rashid, N., Ashfaq, M., Saif, A., Ahmad, N., Han, J., 2013. Global risk of pharmaceutical contamination from highly populated developing countries. Chemosphere 138, 1045-1055.

Santos, J., Aparicio, I., Alonso, E., 2007. Occurrence and risk assessment of pharmaceutically active compounds in wastewater treatment plants. A case study: Seville city (Spain). Environ. Int. 33, 596-601.

Santos, L., Araujo, A., Fachini, A., Pena, A., Delerue-Matos, C., Montenegro, M., 2010 Ecotoxicological aspects related to the presence of pharmaceuticals in the aquatic environment. J. Hazard. Mater. 175, 45-95.

Santos, L., Gros, M., Rodriguez-Mozaz, S., Delerue-Matos, C., Pena, A., Barcelo, D., Montenegro, M., 2013. Contribution of hospital effluents to the load of pharmaceuticals in urban wastewaters: identification of ecologically relevant pharmaceuticals. Sci. Total Environ. 461-462, 302-316.

Schaider, L.A., Ackerman, J.A., Rudel, R.A., 2016. Septic systems as sources of organic wastewater compounds in domestic drinking water wells in a shallow sand and gravel aquifer. Sci. Total Environ. 547, 470-481.

Singh, K.P., Rai, P., Singh, A.K., Verma, P., Gupta, S., 2014. Occurrence of pharmaceuticals in urban wastewater of north Indian cities and risk assessment. Environ. Monit. Assess. 186, 6663-6682.

Shanmugam, G., Sampath, S., Selvaraj, K., Larsson, D., Ramaswamy, B., 2013. Nonsteroidal anti-inflammatory drugs in Indian rivers. Environ. Sci. Pollut. Res. 21, 921-931.

Spongberg, A., Witter, J., 2008. Pharmaceutical compounds in the wastewater process stream in Northwest Ohio. Sci. Total Environ. 397, 148-157.

Stuart, M., Lapworth, D., Crane, E., Hart, A., 2012. Review of risk from potential emerging contaminants in UK groundwater. Sci. Total Environ. 416, 1-21.

Subedi, B., Du, B., Chambliss, C.K., Koschorreck, J., Rüdel, H., Quack, M., Brooks, B.W., Usenko, S., 2012. Occurrence of pharmaceuticals and personal care products in German fish tissue. A National Study, Environ. Sci. Technol. 46, 9047-9054.

Subedi, B., Lee, S., Moon, H.B., Kannan, K., 2014. Emission of artificial sweeteners, select pharmaceuticals, and personal care products through sewage sludge from wastewater treatment plants in Korea. Environ. Int. 68, 33-40.

Subedi, B., Balakrishna, K., Sinha, R., Yamashita, N., Balasubramanian, V., Kannan, K., 2015a. Mass loading and removal of pharmaceuticals and personal care products, including psychoactive and illicit drugs and artificial sweeteners, in five sewage treatment plants in India. J. Environ. Chem. Eng. 3, 2882-2891.

Subedi, B., Codru, N., Dziewulski, D.M., Wilson, L.R., Xue, J., Yun, S., Braun-Howland, E., Minihane, C., Kannan, K., 2015b. A pilot study on the assessment of trace organic contaminants including pharmaceuticals and personal care products from on-site wastewater treatment systems along Skaneateles Lake in New York state, USA. Water Res. 72, 28-39.

Subedi, B., Balakrishna, K., Joshua, D.J., Kannan, K., 2017. Mass loading and removal of pharmaceuticals and personal care products including psychoactives, antihypertensives, and antibiotics in two sewage treatment plants in Southern India. Chemosphere 167, 429-437.

Tixier, C., Singer, H., Oellers, S., Miller, S., 2003. Occurrence and Fate of Carbamazepine, Clofibric Acid, Diclofenac, Ibuprofen, Ketoprofen, and Naproxen in Surface Waters. Environ. Sci. Technol. 37, 1061-1068.

Veach, A., Bernot, M., 2011. Temporal variation of pharmaceuticals in an urban and agriculturally influenced stream. Sci. Total Environ. 409, 4553-4563.

Verlicchi, P., Al Aukidy, M., Galletti, A., Petrovic, M., Barcelo, D., 2012. Hospital effluent: investigation of the concentrations and distribution of pharmaceuticals and environmental risk assessment. Sci. Total Environ. 430, 109-118.

Verstraeten, I.M., Fetterman, G.S., Meyer, M.T., Bullen, T., Sebree, S.K., 2005. Use of tracers and isotopes to evaluate the vulnerability of water in domestic wells to septic waste. Ground Water Monit. Rem. 25, 107-117.

Watkinson, A., Murby, E., Costanzo, S., 2007. Removal of antibiotics in conventional and advanced wastewater treatment: implications for environmental discharge and wastewater recycling. Water Res. 41, 4164-4176.

Wick, A., Fink, G., Joss, A., Siegrist, H., Ternes, T., 2009. Fate of beta blockers and psycho-active drugs in conventional wastewater treatment. Water Res. 43, 1060-1074.

Wilson, B., Smith, V., deNoyelles, F., Larive, C., 2003. Effects of three pharmaceutical and personal care products on natural freshwater algal assemblages. Environ. Sci. Technol. 37, 1713-1719.

Wolf, L., Zwiener, C., Zemann, M., 2012. Tracking artificial sweeteners and pharmaceuticals introduced into urban groundwater by leaking sewer networks. Sci. Total Environ. 430, 8-19.

World Health Organization., 2011. Pharmaceuticals in Drinking-water. 1-49

Xiao, X., McCalley, D., McEvoy, J., 2001. Analysis of estrogens in river water and effluents using solid-phase extraction and gas chromatography - negative chemical ionization mass spectrometry of the pentafluorobenzoyl derivatives. J. Chromatogr. 923, 195-204.

Zou, S., Xu, W., Zhang, R., Tang, J., Chen, Y., Zhang, G., 2011. Occurrence and distribution of antibiotics in coastal water of the Bohai Bay, China: impacts of river discharge and aquaculture activities. Environ. Pollut. 159, 2913-2920. 